\title{
Kejadian Skabies di Beberapa Pondok Pesantren Kota Banjarbaru
}

\author{
The Incidence of Scabies in Several Islamic Boarding School, Banjarbaru City \\ Mifta Rahman Santoso ${ }^{1}$, Noraida ${ }^{{ }^{*}}$, Abdul Khair ${ }^{1}$ \\ ${ }^{1}$ Poltekkes Kemenkes Banjarmasin Jurusan Kesehatan Lingkungan \\ JI.H. Mistar Cokrokusumo No.1A Banjarbaru Kalimantan Selatan 70714 \\ *Korespondensi: noraida1972@gmail.com
}

\begin{abstract}
Scabies is known in Indonesia as scurvy. Scabies is an infectious disease that can be transmitted directly or indirectly. It can be found in densely populated places. Therefore, students who live in Islamic boarding schools are important subjects in this problem. This study aimed to determine the relationship between sanitation and the incidence of scabies in several Islamic boarding schools in Banjarbaru City. This study used an analytical study design that linked sanitation with the incidence of scabies in several Islamic boarding schools in Banjarbaru city. The data was analyzed using the correlation test (Pearson Product Moment). The results showed that food and beverage management had a significant association with the incidence of scabies in several Islamic boarding schools in Banjarbaru city. Other variables had no association with the incidence of scabies. The correlation test results showed that no significant relationship between sanitation and the incidence of scabies in several Islamic boarding schools in Banjarbaru city in 2020 with a p-value of 0,073. Efforts that can be made to reduce the incidence of scabies are maintaining and paying attention to sanitation, especially in the management of food and beverages, maintenance of equipment used for cooking, and sanitation facilities.
\end{abstract}

Keywords: Sanitation, Sarcoptes scabiei, Boarding School

\section{Pendahuluan}

Skabies adalah penyakit infeksi kulit menular yang disebabkan tungau betina Sarcoptes scabiei varieta hominis yang termasuk dalam kelas Arachnida. Penyakit ini paling tinggi terjadi di negara-negara tropis yang merupakan negara endemik penyakit skabies (1). Skabies tidak mengancam jiwa maka penangananya bukan prioritas. Akan tetapi, skabies bisa menjadi kronis dan berat karena dapat menimbulkan komplikasi yang berbahaya. Hal ini disebabkan lesi pada skabies dapat menimbulkan rasa tidak nyaman akibat dari rasa sangat gatal, sehingga penderita sering menggaruk.

Skabies menjadi penyakit yang dapat dengan mudah menular dan ditemukan di tempat berkumpulnya masyarakat. Salah satu tempat umum berkumpulnya masyarakat adalah pondok pesantren. Ditemukan sebanyak $54,7 \%$ responden di Pondok Pesantren Mlangi Nogotirto Sleman Yogyakarta yang terdiagnosis menderita skabies dengan faktor risiko diantaranya adalah Frekuensi kontak tidak langsung dan kepadatan hunian tidak memiliki hubungan dengan kejadian skabies (2). Sedangkan di
Pondok Pesantren Ulumul Qur'an Kecamatan Bebesen Kabupaten Aceh Tengah menyimpulkan adanya hubungan yang signifikan sanitasi lingkungan yang tidak memenuhi syarat berjumlah sebesar $68,3 \%$ (3).

Sanitasi adalah suatu upaya dalam menjaga kondisi lingkungan agar tetap bersih dan terhindar dari serangan penyakit. Sedangkan tempat-tempat umum adalah suatu tempat dimana orang banyak berkumpul dalam berkegiatan baik secara tetap atau rutin. Jadi sanitasi tempat-tempat umum adalah upaya yang dilakukan untuk menjaga kebersihan di tempat yang sering ditemui orang banyak dalam melakukan aktivitas keseharian agar menghindari ancaman dari penyakit (4).

Penularan penyakit secara langsung biasanya terjadi ketika berjabat tangan, tidur bersama dan hubungan seksual, dan penularan secara tidak langsung biasanya melalui benda, contohnya pakaian pribadi perlengkapan tidur dan lain-lain (5). Penyakit skabies di Indonesia biasanya terjadi di daerah perkampungan dan tempat-tempat 
umum yang seringkali kurang diperhatikan kebersihannya (6).

Pondok pesantren atau asrama merupakan tempat yang tersedia untuk para penghuni santri dalam menerima suatu pelajaran agama islam dan sebagai tempat bergabung dan tempat tinggalnya. Santri berasal dari beberapa daerah dengan kebiasaan dan serta pola hidup yang berbeda. Dalam kehidupan keseharian para santri yang tinggal di tempat tersebut seringkali terjadi suatu pertemuan antara santri yang satu dan yang lainnya, yang dapat menyebabkan penyakit menular yang berhubungan dengan lingkungan, salah satunya adalah penyakit kulit. Penyakit ini dapat disebabkan oleh jamur, virus, kuman dan parasit. Penyakit kulit disebabkan oleh parasit dan sering diderita santri adalah penyakit skabies (7).

Berdasarkan data Kementrian Agama Kantor Wilayah Provinsi Kalimantan Selatan tahun 2018, jumlah pondok pesantren yang ada sebanyak 240 pondok pesantren dan tersebar pada 13 kabupaten/kota. Dari data Kementrian Agama Kota Banjarbaru tahun 2018, jumlah Pondok Pesantren yang ada sebanyak 17 pondok pesantren. Jumlah pondok pesantren yang didapat dari data sekunder ada sebanyak 6 pondok pesantren yaitu: Pondok Pesantren Darul IImi, Pondok Pesantren Al Falah, Pondok Pesantren Wali Songo Putra, Pondok Pesantren Walisongo Putri, Pondok Pesantren Waratsatul Fuqaha dan Pondok Pesantren Raudhatun Nasyi'in. Sanitasi menjadi bagian penting untuk diperhatikan dalam penyebaran penyakit menular di pondok pesantren ini, termasuk skabies. Berdasarkan hal tersebut, maka perlu adanya analisis "Kejadian Skabies di Beberapa Pondok Pesantren Kota Banjarbaru".

\section{Metode Penelitian}

Jenis penelitian yang digunakan adalah analitik studi ekologi. Pada penelitian ini, peneliti berupaya menghubungkan sanitasi dengan kejadian penyakit skabies di beberapa pondok pensantren Kota Banjarbaru.

Total populasi adalah seluruh data kasus penderita skabies yang ada di Puskesmas kota Banjarbaru, yang berasal dari pondok pesantren. Penelitian ini menggunakan teknik accidental sampling. Metode ini dilaksanakan dengan cara mengambil responden yang kebetulan ada di suatu tempat sesuai dengan lokasi penelitian (8). Responden adalah santri yang ada di pondok pesantren

Data penelitian dikumpulkan dengan cara wawancara serta pengumpulan data tentang sanitasi dan skabies di pondok pesantren. Wawancara dilakukan dengan pihak pengelola pondok pesantren. Data atau dokumen yang didapat dari pihak pengelola pondok pesantren dan puskesmas dimasukkan dalam tabel distribusi frekuensi.

Uji korelasi digunakan untuk mengetahui hubungan antara sanitasi dengan kejadian skabies di beberapa pondok pesantren di kota Banjarbaru.

\section{Hasil}

Hasil data diperoleh penilaian sanitasi di beberapa pondok pesantren di kota Banjarbaru tahun 2020.

Tabel 1. Penilaian Sanitasi di Pondok Pesantren Kota Banjarbaru

\begin{tabular}{lccc}
\hline \multicolumn{1}{c}{ Pondok Pesantren } & Sanitasi & Standar & Ket $^{*}$ \\
\hline Darul IImi & 4.803 & $\geq 3.756$ & $\mathrm{MS}$ \\
Al Falah & 4.555 & $\geq 3.756$ & $\mathrm{MS}$ \\
Wali Songo Putra & 7.290 & $\geq 6.240$ & $\mathrm{MS}$ \\
Wali Songo Putri & 6.830 & $\geq 6.240$ & $\mathrm{MS}$ \\
Waratsatul Fuqaha & 6.520 & $\geq 6.240$ & $\mathrm{MS}$ \\
Raudhatun Nasyi'in & 8.650 & $\geq 6.240$ & $\mathrm{MS}$ \\
\hline
\end{tabular}

${ }^{*} \mathrm{MS}=$ Memenuhi Syarat

Pada Tabel 1, diketahui bahwa untuk memenuhi syarat minimal $\geq 3.756$ untuk Pondok Pesantren Darul IImi dan Al Falah. Sedangkan untuk memenuhi syarat minimal $\geq 6.240$ untuk Pondok Pesantren Wali Songo Putra dan Putri, Waratsatul Fuqaha, dan Raudhatun Nasyi'in.

\section{Lokasi Bangunan dan Kejadian Skabies}

Tabel 2. Lokasi Bangunan dan Kejadian Skabies

\begin{tabular}{lcc}
\hline Pondok Pesantren & $\begin{array}{c}\text { Lokasi } \\
\text { Bangunan }\end{array}$ & Skabies \\
\hline Darul Ilmi & 135 & 25 \\
Al Falah & 120 & 27 \\
Wali Songo Putra & 390 & 21 \\
Wali Songo Putri & 150 & 12 \\
Waratsatul Fuqaha & 285 & 17 \\
Raudhatun Nasyi'in & 360 & 15 \\
\hline Total & 1.440 & 117 \\
\hline
\end{tabular}


Pada Tabel 2, diketahui total skor lokasi bangunan sebesar 1.440 dan 117 orang yang mengalami penyakit skabies. Berdasarkan hasil uji korelasi dengan tingkat signifikan (nilai alpha) 0,05 di peroleh nilai $p=0,498$. Karena nilai $p=0,498>$ nilai alpha 0,05 maka Ho diterima. Hal ini berarti tidak ada korelasi antara lokasi bangunan dengan kejadian skabies di beberapa pondok pesantren di kota Banjarbaru pada tahun 2020.

\section{Konstruksi Bangunan dan Kejadian Skabies}

Tabel 3. Konstruksi Bangunan dan Kejadian Skabies

\begin{tabular}{lcc}
\hline \multicolumn{1}{c}{ Pondok Pesantren } & $\begin{array}{c}\text { Konstruksi } \\
\text { Bangunan }\end{array}$ & Skabies \\
\hline Darul IImi & 1.950 & 25 \\
Al Falah & 2.025 & 27 \\
Wali Songo Putra & 3.055 & 21 \\
Wali Songo Putri & 3.075 & 12 \\
Waratsatul Fuqaha & 2.472 & 17 \\
Raudhatun Nasyi'in & 3.500 & 15 \\
\hline Total & 16.077 & 117 \\
\hline
\end{tabular}

Pada Tabel 3, diketahui total skor konstruksi bangunan sebesar 16.077 dan 117 orang yang mengalami penyakit skabies. Berdasarkan hasil uji korelasi dengan tingkat signifikan (nilai alpha) 0,05 di peroleh nilai $p=0,063$. Karena nilai $p=0,063>$ nilai alpha 0,05 maka Ho diterima. Hal ini berarti tidak ada korelasi antara konstruksi bangunan dengan kejadian skabies di beberapa pondok pesantren di kota Banjarbaru pada tahun 2020.

3. Ruang Tidur dengan Kejadian Skabies Tabel 4. Ruang Tidur dan Kejadian Skabies

\begin{tabular}{lcc}
\hline \multicolumn{1}{c}{ Pondok Pesantren } & $\begin{array}{c}\text { Ruang } \\
\text { Tidur }\end{array}$ & Skabies \\
\hline Darul Ilmi & 200 & 25 \\
Al Falah & 110 & 27 \\
Wali Songo Putra & 440 & 21 \\
Wali Songo Putri & 260 & 12 \\
Waratsatul Fuqaha & 220 & 17 \\
Raudhatun Nasyi'in & 420 & 15 \\
\hline Total & 1.650 & 117 \\
\hline
\end{tabular}

Pada Tabel 4, diketahui total skor ruang tidur sebesar 1.650 dan 117 orang yang mengalami penyakit skabies. Berdasarkan hasil uji korelasi dengan tingkat signifikan (nilai alpha) 0,05 di peroleh nilai $p=0,342$. Oleh karena $p=0,342>$ nilai alpha 0,05 maka Ho diterima. Hal ini berarti tidak ada korelasi antara ruang tidur dengan kejadian skabies di beberapa pondok pesantren di kota Banjarbaru pada tahun 2020.

\section{Fasilitas Sanitasi dan Kejadian Skabies}

Tabel 5. Fasilitas Sanitasi dan Kejadian Skabies

\begin{tabular}{lcc}
\hline \multicolumn{1}{c}{ Pondok Pesantren } & $\begin{array}{c}\text { Fasilitas } \\
\text { Sanitasi }\end{array}$ & Skabies \\
\hline Darul IImi & 1.838 & 25 \\
Al Falah & 1.700 & 27 \\
Wali Songo Putra & 2.140 & 21 \\
Wali Songo Putri & 2.120 & 12 \\
Waratsatul Fuqaha & 1.740 & 17 \\
Raudhatun Nasyi'in & 2.700 & 15 \\
\hline Total & 12.238 & 117 \\
\hline
\end{tabular}

Pada Tabel 5, diketahui total skor fasilitas sanitasi sebesar 12.238 dan 117 orang yang mengalami penyakit skabies. Berdasarkan hasil uji korelasi dengan tingkat signifikan (nilai alpha) 0,05 di peroleh nilai $p=0,229$. Karena nilai $p=0,229>$ nilai alpha 0,05 maka Ho diterima. Hal ini berarti tidak ada korelasi antara fasilitas sanitasi dengan kejadian skabies di beberapa pondok pesantren di kota Banjarbaru pada tahun 2020.

\section{Pengelolaan Makanan Minuman dan Kejadian Skabies}

Tabel 6. Pengelolaan Makanan Minuman dan Kejadian Skabies

\begin{tabular}{lcc}
\hline Pondok Pesantren & $\begin{array}{c}\text { Pengelolaan } \\
\text { Makanan } \\
\text { Minuman }\end{array}$ & Skabies \\
\hline Darul Ilmi & 680 & 25 \\
Al Falah & 600 & 27 \\
Wali Songo Putra & 1090 & 21 \\
Wali Songo Putri & 1480 & 12 \\
Waratsatul Fuqaha & 1900 & 17 \\
Raudhatun Nasyi'in & 1420 & 15 \\
\hline Total & 7.170 & 117 \\
\hline
\end{tabular}

Pada Tabel 6, diketahui total skor pengelolaan makanan dan minuman sebesar 7.170 dan 117 orang yang mengalami penyakit skabies. Berdasarkan hasil uji korelasi dengan tingkat signifikan (nilai alpha) 0,05 di peroleh nilai $p=0,036$. Karena nilai $p=0,036$ < nilai alpha 0,05 maka Ho ditolak. Hal ini berarti ada korelasi antara pengelolaan makanan dan minuman dengan kejadian skabies di beberapa pondok pesantren di kota Banjarbaru pada tahun 2020. 


\section{Pembahasan}

\section{Lokasi Bangunan dan Kejadian Skabies}

Tidak ada korelasi antara lokasi dan bangunan dengan kejadian skabies di beberapa pondok pesantren di kota Banjarbaru. Hal ini sesuai dengan penelitian yang dilaksanakan oleh Julia (9), yang menyatakan bahwa kebersihan lingkungan tidak berhubungan dengan kejadian skabies.

\section{Konstruksi Bangunan dan Kejadian Skabies}

Tidak ada korelasi antara konstruksi bangunan dengan kejadian skabies di beberapa pondok pesantren. Hal ini sesuai dengan penelitian yang dilaksanakan oleh Parasibu dkk (10) yang menyatakan bahwa tidak ada hubungan antara ventilasi, kelembaban, dan pencahayaan dengan kejadian skabies.

\section{Ruang Tidur dan Kejadian Skabies}

Tidak ada korelasi antara ruang tidur dengan kejadian skabies di beberapa pondok pesantren. Hal ini sesuai dengan penelitian yang dilaksanakan oleh Parasibu dkk (10) yang menyatakan bahwa tidak ada hubungan antara kebersihan tempat tidur dan sprai dengan kejadian skabies.

\section{Fasilitas Sanitasi dan Kejadian Skabies}

Tidak ada korelasi antara fasilitas sanitasi dengan kejadian skabies di beberapa pondok pesantren.

Menurut Khairani, variabel sanitasi lingkungan rumah yang berhubungan dengan kejadian skabies yaitu kualitas fisik air (11). Air merupakan kebutuhan yang paling penting untuk kelangsungan hidup manusia, oleh karena itu diperlukan air yang kualitasnya memenuhi syarat kesehatan. Air yang tidak memenuhi syarat kesehatan dapat sebagai media penularan penyakit, salah satunya penyakit skabies. Seseorang dapat terkena penyakit skabies jika mandi di air yang kotor, dimana air kotor tersebut telah tercemar.

\section{Pengelolaan Makanan Minuman dan Kejadian Skabies}

Ada korelasi antara pengelolaan makanan dan minuman dengan kejadian skabies di beberapa pondok pesantren Kejadian skabies justru dipengaruhi oleh hygiene perseorangan dan status gizi. Menurut Currie dan Walton bahwa status gizi yang buruk dapat menyebabkan tingkat imunitas individu menurun dan pada akhirnya dapat meningkatkan kejadian penyakit dalam diri individu maupun suatu komunitas. Pada responden yang status gizinya kurang makan akan mudah terserang penularan skabies. Adanya ketahanan pangan, pengetahuan tentang asupan gizi dan pola pengasuhan anak yang baik maka akan mengurangi resiko menurunya imunitas dan antibody tubuh, sehingga tidak mudah terserang infestasi tungau (12).

Ada hubungan antara status nutrisi dengan skabies dapat dijelaskan bahwa ketika status nutrisi dalam tubuh baik maka dapt meningkatkan antibody tubuh dan tubuh tidah mudah terserang virus skabies. Tubuh butuh energy untuk aktivitas sehingga dibutuhkan intake nutrisi yang tepat dan mencukupi. Nutrien merupakan elemen penting dalam proses dan fungsi tubuh. Nutrien mencakup karbohidrat, protein, lemak, vitamin, mineral, dan air. Status gizi adalah suatu keadaan tubuh yang di akibatkan oleh keseimbangan antara asupan zat gizi dengan kebutuhan (13).

Hal ini sejalan dengan buku Inspeksi Sanitasi Tempat-Tempat Umum bahwa untuk luas dapur minimal $40 \%$ dari ruang makan, sedangkan untuk syarat penghawaan harus dilengkapi dengan pengeluaran udara panas maupun bau-bauan (exhauser) yang dipasang setinggi 2 meter dari lantai, pada tungku dapur dilengkapi dengan sungkup atap (hood). Sementara pertukaran udara diusahakan dengan ventilasi yang dapat menjamin kenyamanan, menghilangkan debu dan asap. Untuk bahan dan peralatan dipersyaratkan antara lain, pada bahan makanan/minuman yang diolah harus dalam keadaan baik, tidak rusak, atau berubah bentuk warna dan rasa, bahan terolah harus dikemas dan bahan tambahan harus memenuhi persyaratan kesehatan. Sedangkan peralatan memasak dan peralatan makan/minum, dipersyaratkan permukaan harus mudah dibersihkan, tidak terbuat dari bahan yang mengandung timah hitam, tembaga, seng, kadmium, arsenikum, dan antimon, sementara ruang tempat penyimpanan alat-alat terlindung dan tidak lembab (4). 


\section{Kesimpulan}

Terdapat korelasi antara pengelolaan makanan dan minuman dengan kejadian skabies. Sedangkan lokasi dan bangunan, konstruksi bangunan, ruang tidur, dan fasilitas sanitasi menunjukkan tidak ada korelasi dengan kejadian skabies. Upaya yang dapat dilakukan untuk menurunkan angka kejadian skabies antara lain menjaga dan memperhatikan sanitasi terutama dibagian pengelolaan makanan dan minuman. Melengkapi peralatan pada saat memasak.

\section{Daftar Pustaka}

1. Desmawati, Dewi AP, dan Hasanah O. Hubungan Personal Hygiene dan Sanitasi Lingkungan dengan Kejadian Skabies di Pondok Pesantren Al-Kautsar Pekanbaru. JOM/. 2(1): 628-637; 2015.

2. Hilma, UD., Ghazali L. Faktor-Faktor yang Mempengaruhi Kejadian Skabies di Pondok Pesantren Mlangi Nogotirto Gamping Sleman Yogyakarta. JKKI. 6(3): 148-157; 2014.

3. Wulandari, A. Hubungan Personal Hygiene dan Sanitasi Lingkungan dengan Kejadian Skabies pada Santri di Pesantren Ulumul Qur'an Kecamatan Bebesan Kabupaten Aceh Tengah. Global Health Science. 3(4): 322-328; 2018.

4. Santoso, I. Inspeksi Sanitasi Tempattempat Umum. Yogyakarta: Gosyen Publishing; 2019.

5. Djuanda. IImu Penyakit Kelamin dan Kulit. Jakarta: Fakultas Kedokteran Universitas Indonesia; 2006.

6. Safar, Rosdiana. Parasitologi Kedokteran. Bandung: Yrama Widya; 2010.
7. Kuspriyanto. Hubungan antara Praktik Kebersihan Diri dengan Kejadian Skabies pada Santri di Pondok Pesantren. Universitas Surakarta; 2002.

8. Notoatmodjo. Metodologi Penelitian Kesehatan. Jakarta: PT. Rineka Cipta; 2010.

9. Julia R, Utami BTS. Hubungan Faktor Lingkungan dan Perilaku terhadap Kejadian Skabies di Pondok Pesantren Al-Furqon Kecamatan Sidayu Kabupaten Gresik Provinsi Jawa Timur Tahun 2013. Fakultas Kesehatan Masyarakat Universitas Indonesia. Skripsi. 2013.

10. Pasaribu AH., Nurmaini, Santi DN, Hubungan Sanitasi Lingkungan dan Higiene Perseorangan dengan Kejadian Skabies di Rutan Cabang Sibuhuan Kabupaten Padang Lawas Tahun 2013. Jurnal Lingkungan dan Keselamatan Kerja. 3(2); 2014.

11. Khairani, Al. Sanitasi Lingkungan Rumah dan Sosial Budaya Masyarakat Pesisir Pantai terhadap Kejadian Skabies. Jurnal Riset Hesti Medan. 1(1); 2016.

12. Putri, BSSA., Margawati, A. Hubungan Higiene Perseorangan, Sanitasi Lingkungan dan Status Gizi Terhadap Kejadian Skabies pada Anak (Studi kasus di Sekolah Dasar Negeri 3 Ngablak, Magelang). Fakultas Kedokteran Universitas Diponegoro. Skripsi. 2011.

13. Fitriawati, Ruhyana. Hubungan Faktor Personal Hygiene, Sanitasi Lingkungan, dan Status Nutrisi dengan Kejadian Scabies pada Santriwati di Pondok Pesantren Nurul Ummah Kotagede Yogyakarta. STIKES 'Aisyiyah Yogyakarta. Skripsi. 2014. 